\author{
Natalia Cichoń \\ Uniwersytet Jagielloński, Kraków \\ natalia.cichon@doctoral.uj.edu.pl
}

\title{
Epyllion w badaniach naukowych - antyczne genus mixtum?
}

\section{Abstract \\ Studies on Epyllion: Is It an Antique Genus Mixtum?}

In this paper, the author attempts to answer the question whether epyllion (miniature epic poem) was regarded a coherent genre in antiquity or if this attribution is an invention of modern scholars. Today, the term is commonly used by philologists and theoreticians of literature in various languages, but a scholar who does not know its provenience is unable to fully comprehend the character of this genre. As a genre, epyllion occurred in literary studies and in the vocabulary of literary criticism as late as in the $19^{\text {th }}$ century in Germany, gradually spreading to other countries. During the Renaissance, it appeared sporadically and usually referred to contemporary texts. In antiquity, however, it was used only a few times: and while it appeared in a literary context, it never meant short epic poem. Today's understanding of this term is then significantly different from that used by the ancients. Nonetheless, epyllion is commonly regarded an antique literary genre that emerged in the Hellenistic period as a reaction to and spinoff from the long heroic epic.

The author demonstrates that classical texts are often interpreted by use of modern methods, which classify them differently from how it was done in the antiquity. In the first part of the paper, she presents the notion of epyllion as it was understood according to the antique theory of literature. Next, different accounts on using this term over the course of time are discussed: from the antiquity, through the late Byzantium and Renaissance, to the modern times. The analysis of research concerning this genre leads the author to the conclusion that epyllion did not emerge from 
the genologic theory of classical authors but rather from the modern concept of literature. This conclusion is also supported by the fact that certain poems written when the "antique" miniature epos drew the attention of German scholars resembled some of ancient Greek works, which in turn were soon referred to in similar terms. This coincidence can hardly be considered accidental.

Key words: epyllion, miniature epos, epic, genus mixtum, literary genre, antic genres

Powstałe w starożytności określenie ė $\pi \dot{\lambda} \lambda \lambda_{\iota}$ ov, czyli zdrobnienie od słowa हैंлoৎ, w językach nowożytnych tłumaczone jest jako epos miniaturowy, short epic, das Kleinepos czy lepica breve i w tym znaczeniu powszechnie używane przez współczesnych filologów. Jednak żadne $\mathrm{z}$ dzisiejszych tłumaczeń nie odzwierciedla w pełni znaczenia tego wyrazu znanego Grekom i Rzymianom. Do dziś zachowało się siedem poświadczeń tego wyrażenia z czasów antycznych - pięć w języku greckim i dwa po łacinie ${ }^{1}$ - aczkolwiek niemal ani razu nie określało ono krótkich form narracyjnych, czy to heksametrycznych, czy elegijnych (choć zawsze pojawiało się w kontekście literackim)².

1 Wyrażenia tego używa trzykrotnie Arystofanes w odniesieniu do fragmentu poetyckiego bądź wersu (Acharn. 398-400, Pax 531, Ranae 94). Pojawia się ono też dwukrotnie u Atenajosa na określenie utworu Epikichlides przypisywanego Homerowi (II 65a-b, XIV 369a). Kolejne greckie poświadczenia znajdują się u Klemensa Aleksandryjskiego (Strom. III 3,24) oraz w greckim leksykonie Hezychiusza z V wieku n.e.; dotyczą one fragmentów poezji, ale nie definiują jej jasno jako krótki epos. Z kolei dwóch łacińskich źródeł dostarcza twórczość Auzoniusza (Symm. 335,56-58 - w odniesieniu do poematu Symmachusa; Cent. Nupt. 360,14-15 - tu termin „epyllion" odnosiłby się do erotycznych epigramów lub upoetyzowanej prozy). Zob. J. F. Reilly, Origins of the Word Epyllion, „Classical Journal” 49 (1953), s. 111.

2 Więcej na ten temat: zob. m. in. S. Tilg, On the Origins of the Modern Term "Epyllion": Some Revisions to a Chapter in the History of Classical Scholarship, w: Brill's Companion to Greek and Latin Epyllion and Its Reception, ed. by M. Baumbach, S. Bär, Leiden - Boston 2012, s. 29; W. Allen, The Epyllion: A Chapter in the History of Literary Criticism, „Transactions and Proceedings of the American Philological Association" 71 (1940); D. Bright, The Miniature Epic in Vandal Africa, London 1987, s. 3. 
Jednakże od okresu archaicznego aż po późny antyk powstawały utwory, w których współcześni uczeni, począwszy od pierwszej połowy XIX wieku, zauważyli pewną konwencję, charakterystyczne cechy wspólne ${ }^{3}$. Stało się to dla nich impulsem do badań nad tym, czy należy te pieśni zakwalifikować do osobnej grupy lub nawet gatunku, a na jego określenie, $\mathrm{z}$ powodu luki w antycznym systemie klasyfikacji gatunkowej, zaczęli używać terminu „epyllion”.

\section{Problemy genologii antycznej}

Metoda pracy nowożytnych filologów polegająca na klasyfikowaniu i przyporządkowywaniu każdego utworu do konkretnej kategorii stawia przed nauką o literaturze antycznej liczne problemy. Teksty klasyczne nierzadko interpretowane są wedle współczesnych rozwiązań, co często rozmija się z tym, jak rozumiano i klasyfikowano dane utwory w starożytności. Aby podjąć próbę odpowiedzi na pytanie, czy utwory, które przez współczesnych badaczy zaliczane są do grona epyllionów, uchodziły w antyku za osobny, koherentny

3 Pośród utworów powszechnie uznawanych za epylliony antyczne wylicza się - dla okresu hellenistycznego: idylle Teokryta (13, 22 i 24), 'Екá $\lambda \eta$ (Hekale) Kallimacha, Eủpẃrn (Europa) Moschusa; dla twórczości neoteryków oraz poezji augustowskiej: Zmyrna Helwiusza Cynny, Io Licyniusza Kalwusa, carmen 64 Katullusa, historię Arysteusza jako epyllion wpisany w Georgikę 4 Wergiliusza (wersy 315558) oraz historię Nizusa i Euryalusa z 9 księgi Eneidy Wergiliusza (ww. 182-234), Culex (Komar) i Ciris (Mewa) zachowane w Appendix Vergiliana; dla epoki późnego

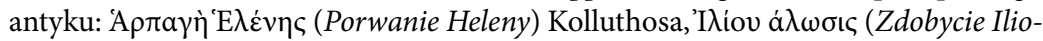

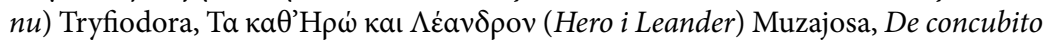
Martis et Veneris (O zaślubinach Marsa $i$ Wenus) Repozjanusa, cztery utwory Drakoncjusza - Hylas, De raptu Helenae (O porwaniu Heleny), Medea, Orestis Tragoedia (Tragedia Orestesa) oraz anonimowy epyllion Aegritudo Perdicae (Choroba Perdyka-

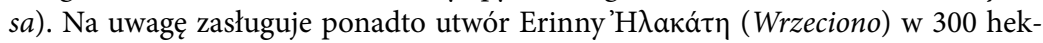
sametrach, datowany na przełom IV i III wieku p.n.e., w którym poetka wysławia swą przyjaciółkę Baukis - napisany w metrum epickim, jednak tematyką bardzo od epiki różny, wpasowujący się w konwencję epyllionu. 
gatunek, w pierwszej kolejności należy przyjrzeć się temu, jak w ówczesnej teorii genologicznej rozumiano pojęcie gatunku literackiego oraz jakie zagadnienia poruszali teoretycy literatury.

Pierwsze systematyczne podsumowanie teorii literatury greckiej stanowi Poetyka Arystotelesa. W swych rozważaniach filozof wiele zawdzięczał swemu mistrzowi, Platonowi, który wprawdzie nie opracował dla swych poglądów konkretnego systemu ${ }^{4}$, często jednak wypowiadał się na temat poezji w dialogach, zwłaszcza w Państwie, Prawach, Ionie i Fajdrosie. Platon jako pierwszy wypracował teorię naśladowania $(\mu i \mu \eta \sigma \iota)^{5}$, pod pewnymi względami kontynuowaną przez Arystotelesa, w którego mniemaniu mímesis to akt twórczy, akt kreowania potencjalnej rzeczywistości odzwierciedlającej życie ludzkie ${ }^{6}$, stanowiący wspólny aspekt wszelkich elementów poezji oraz najważniejszy czynnik oddzielający poezję od innych sztuk. Według Arystotelesa nie można bowiem określić tym samym mianem $\mathrm{z}$ jednej strony autorów traktatów z zakresu przyrody i medycyny, a $\mathrm{z}$ drugiej strony Homera - nawet jeśli tworzyli oni w tym samym metrum; na miano poety zasługuje jedynie ten, kto uprawia sztukę naśladowania (Poet. 1447 $1-24)$.

Stagiryta poruszył ponadto zagadnienie „czystości” gatunków literackich, które to zagadnienie warto przybliżyć ze względu na kwestię intergatunkowości epyllionu, już Arystoteles wskazał bowiem

4 Myśli Platona na temat poezji najpełniej można zrozumieć w świetle jego filozofii i założeń państwa idealnego - dlatego np. zwracał tak dużą uwagę na wychowanie jako jedno z najważniejszych zadań sztuki (Plat. Res Publ. 376c-402a).

5 Platon uważał, że sztuka jest naśladownictwem wykreowanej przez człowieka rzeczywistości. Opierając się na kryterium mímesis, Platon podzielił poezję na trzy klasy: tragedia i komedia jako utwory całkowicie polegające na formie naśladowniczej; dytyramb jako utwór posługujący się formą opowiadania poety, bez zastosowania mímesis; epika - czyli utwór powstały przy zastosowaniu obu sposobów wypowiedzi (Plat. Res Publ. 394c).

6 Arist. Poet. 1451 ${ }^{\mathrm{b}} 26-29$ : „poeta powinien być raczej twórcą fabuły (w oryg.: $\mu v \dot{\theta} \omega \nu$ - słowa) niż wiersza ( $\mu \varepsilon \dot{\tau} \rho \omega v)$, skoro właśnie jest poetą ze względu na sztukę

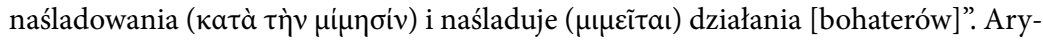
stoteles, Poetyka, przeł. H. Podbielski, Wrocław 2006, s. 32. 
na istnienie mieszanych odmian gatunkowych. Podzielił dwa główne gatunki - tragedię i epos - na cztery podtypy (Poet. 1459'b-10): pro-

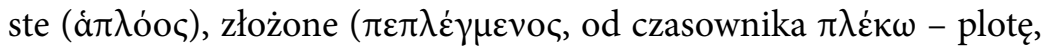

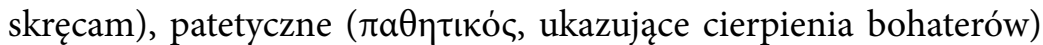

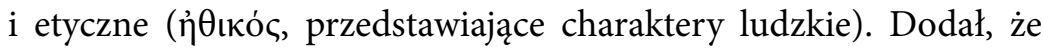
konkretne dzieła mogą powstać z kombinacji dwóch odmian (które ze swej natury powinny się wykluczać) - prostej z patetyczną i złożonej z etyczną, a jako przykłady pierwszych tego typu utworów podał Iliadę i Odyseję (Poet. 1469 $\left.{ }^{\mathrm{b}} 12-15\right)$.

Spośród teoretyków epoki hellenistycznej warci uwagi są przede wszystkim Neoptolemos z Parion oraz Filodemos z Gadary. Neoptolemos wprowadził bądź rozpowszechnił ${ }^{8}$ trójpodział przedmiotów

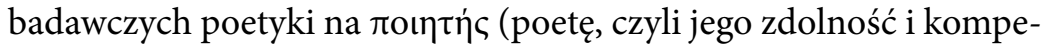

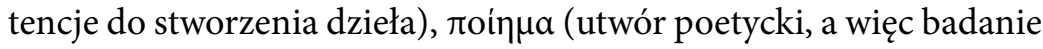
kompozycyjno-formalnych składników wypowiedzi oraz technikę

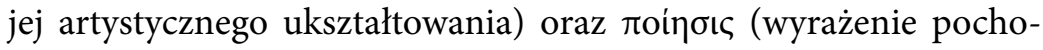
dzące od greckiego terminu roı́́ - czynię, tłumaczone jako poezja, a skupiające się na warstwie treściowej utworu niosącej pewne idee, emocje) ${ }^{9}$. Podział ten stanowi częsty punkt odniesienia w pismach Filodemosa. Skrytykował go w dziele O utworach poetyckich: „Niedorzeczne jest też, iż tego, kto opanował rzemiosło i posiada talent poetycki, uznał [Neoptolemos] - obok poematu ( $\pi$ oin $\mu \alpha)$ i poezji

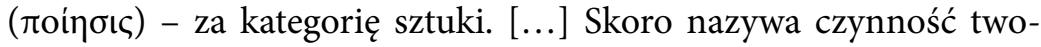
rzenia poetyką - a termin ten wiąże się ze sztuką - to nie zna się na

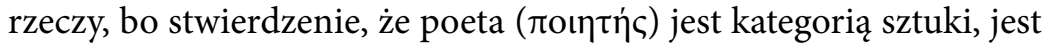
śmieszne" (De poem. $\mathrm{N} \mathrm{XI}^{10}$ ). Filodemos nie aprobował uznawania poety za przedmiot poetyki, ponadto, jak wynika z dalszej części po-

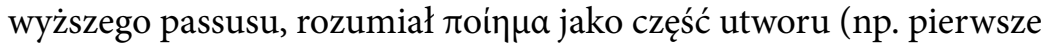

7 Zob. E. Asmis, Neoptolemus and the Classification of Poetry, „Classical Philology" 87 (1992), no. 3, s. 212.

8 Zob. Filodemos, O muzyce. O utworach poetyckich. Epigramy, przeł. K. Bartol, Warszawa 2002, s. 33.

9 Podział ten znamy m.in. dzięki Filodemosowi, De poem. N XI.

10 Filodemos, O muzyce..., s. 90. 
30 wersów Iliady), זoínбıৎ natomiast jako cały utwór. Z czasem wy-

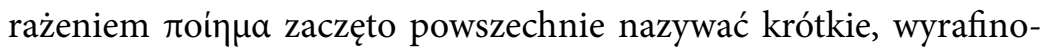
wane stylistycznie poematy w opozycji do długich utworów określanych mianem $\pi$ oin $\iota^{11}{ }^{11}$. Tę teorię wyznawał także tworzący krótko przed Filodemosem autor satyr Lucyliusz. Dla niego poema to niewielka część, pars parva, jak na przykład list, z kolei poesis to opus totum, czyli całe dzieło, czego przykładem może być Iliada Homera lub Annales Enniusza (Sat. 9,339-947).

Jak można zatem wywnioskować z teorii literackiej Arystotelesa oraz autorów okresu hellenistycznego, skupiano się wówczas przede wszystkim na kwestiach dotyczących procesu twórczego oraz starano się usystematyzować kwestie dotyczące samych dzieł, aczkolwiek dzieła te podporządkowywano jedynie kanonicznym gatunkom: pod uwagę brane były głównie epos, tragedia, komedia. Teoretyków interesowała wartość utworu, styl (ozdobność, dostojność), a także czynniki stanowiące o tym, czy dany poeta był dobry i użyteczny. Zwracali oni uwagę także na długość utworu, jednak nie mieli potrzeby określania powstających wówczas krótkich i innych gatunków - pole badań do analizy stanowił krąg gatunków „podstawowych” wywodzących się z epoki archaicznej.

\section{Epyllion w epoce hellenistycznej}

Najsłynniejszym krótkim eposem tych czasów jest Hekale Kallimacha traktujący o zabiciu byka maratońskiego przez Tezeusza - na przykładzie tego utworu omówię stosunek epyllionu do tradycyjnego

1 Zob. K. Gutzwiller, The Hecale and Hellenistic Conceptions of Short Hexameter Narratives, w: Brill's Companion to Greek and Latin Epyllion and Its Reception, ed. by Manuel Baumbach, Silvio Bär, Leiden - Boston 2012, s. 229; K. Gutzwiller, Studies in the Hellenistic Epyllion, Königstein 1981, s. 229-230; E. Asmis, Neoptolemus and the Classification of Poetry..., s. 213. 
eposu. Autor scholium do kallimachejskiego Hymnu do Apollona zasugerował, iż Kallimach stworzył Hekale jako odpowiedź na zarzuty,

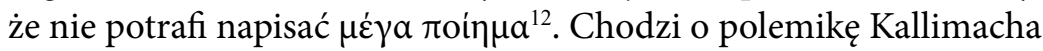
ze współczesnymi mu krytykami określonymi mianem Telchinów (złośliwych demonów) w prologu Aitiów, utworu niezwykle ważnego dla poznania zasad kallimachejskiej poetyki. Poeta propagował małą formę poetycką oraz wskazał typ poezji, której pragnął unikać: rozwlekłej i pompatycznej (ww. 13-20). Kolejne wersy reprezentują jego hasło programowe: wedle zaleceń Apollona miał dbać o drobną ( $\lambda \varepsilon \pi \tau a \lambda \varepsilon ́ \eta v)$ Muzę oraz podążać własną drogą (ww. 21-28).

Jak wynika ze wzmianki u Filodemosa, który wspomina pewne-

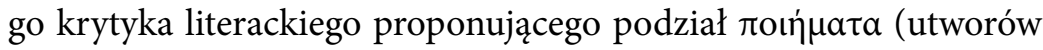

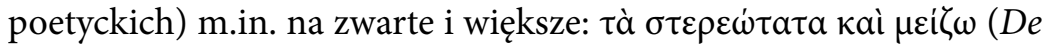
poem. N V), określenie $\mu \varepsilon i ́(\omega$ (forma pochodząca od $\mu \dot{\varepsilon} \gamma \alpha \varsigma$ ) odnosiło się zarówno do długości, jak i do stylu: podniosłego i bogatego ${ }^{13}$. Na określenie długości poematu używano natomiast określenia $\mu \alpha \kappa \rho \varsigma^{14}$

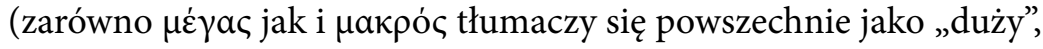
„wielki”, stąd problem w interpretacji). Stawiane Kallimachowi za-

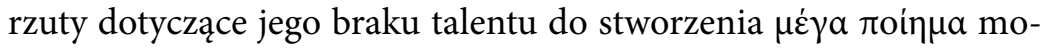
gły się zatem odnosić nie tylko do pisania wielkiej (długiej, homeryckiej) epiki, lecz także ogólnie „dobrego utworu” o wyszukanym, podniosłym stylu. Sam Kallimach użył kilkakrotnie wyrażenia $\mu \dot{\gamma} \gamma a \varsigma$ w uwagach krytycznych wplecionych w swoją poezję: w kontraście

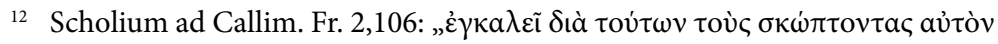

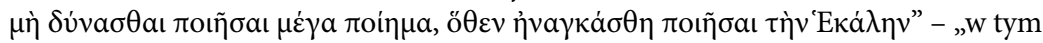
passusie [Kallimach] wini tych, którzy naśmiewali się z niemożności stworzenia przez niego wielkiego poematu, przez co zmuszony został do napisania Hekale" (tłum. własne). To oskarżenie skojarzyć można z teorią Neoptolemosa dotyczącą zdolności poety do stworzenia dobrego dzieła jako niezbędnego elementu ówczesnej poetyki.

13 Zob. K. Gutzwiller, The Hecale and Hellenistic Conceptions of Short Hexameter Narratives..., s. 225.

14 Zob. K. Gutzwiller, Studies in the Hellenistic Epyllion..., s. 222-237. 
do krótkiej poezji Mimnermosa (fr. 1,12: $\mu \varepsilon \gamma \alpha \dot{\lambda} \lambda \eta)$ czy też w słynnym

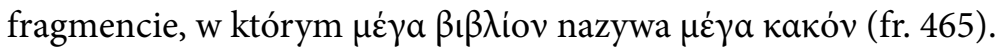

Epyllion aleksandryjski to zatem epika pisana w nowej manierze poddającej się wpływom epoki; rodzaj manifestu ukazującego, w jaki sposób poeta miał traktować tradycyjny temat i formę epicką. Jego stosunkowo krótka forma nie była oryginalna (krótkie utwory tworzono już wcześniej), nietypowe było natomiast ujęcie tematu - od zasad tradycyjnej epiki odbiegało rozłożenie akcentów ${ }^{15}$ czy wybór epizodów.

\section{Wydania Teokryta i Katullusa jako zapowiedź pojawienia się epyllionu $w$ nauce}

Epyllion nie stanowił odrębnego gatunku ani w zachowanych korpusach twórczości poszczególnych poetów, ani w teorii literatury spisanej w antyku - a przynajmniej nie mamy na to żadnych poświadczeń. Kiedy zatem zauważono, że niektóre spośród utworów danego poety wyróżniają się na tle pozostałych pod względem narracji? Co do koherencji korpusu twórczości Teokryta, już w okresie późnego Bizancjum zaobserwowano, że nie wszystkie jego utwory to bukoliki, lecz że jego twórczość cechuje różnorodność gatunkowa. Mianowicie Demetrios Triklinios w notatkach do poematów Teokryta w manuskrypcie z XIV wieku (Paris BN 3832) zaklasyfikował niektóre z nich z powodu odmiennej narracji do podgatunków (sub-genres) i okre-

15 W Hekale uwagę zwraca potraktowanie skrótowo głównego tematu dzieła (zabicia byka maratońskiego), podczas gdy inne elementy, mniej istotne dla fabuły, zajmują stosunkowo dużo miejsca, np. motywy aitiologiczne. Podobnie w epyllionach późnoantycznych: Kolluthos w Porwaniu Heleny znaczną część utworu poświęca na żale Hermiony porzuconej przez Helenę, z kolei Drakoncjusz w utworze o tym samym tytule zastanawia się nad wszelkimi przyczynami wojny, ponad 200 wersów poświęcając wyprawie na Salaminę w celu odebrania Hezjone. 


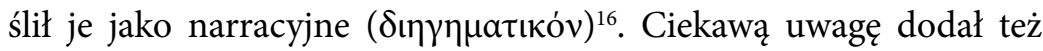
w XVI wieku Veit Winscheim - do gatunku narracyjnego przypisał te utwory Teokryta, które później zostały uznane właśnie za epylliony

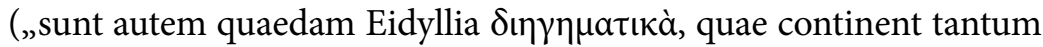
narrationes"17). Co więcej, jak można wywnioskować ze wstępów do wydań humanistycznych (które z kolei podążały za tradycją przekazywaną we wcześniejszych scholiach) wyrażenie eidyllion ( - tłumaczone jako drobny utwór poetycki, zdrobnienie od słowa

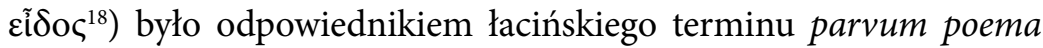
bądź parvum carmen, co doskonale wpisuje się w późniejszą definicję samego epyllionu ${ }^{19}$. Kolejnym krokiem zapowiadającym tę konwencję jest pochodzący z 1789 roku komentarz Friedricha von Finkensteina, który zauważył, że spośród trzydziestu idylli Teokryta tylko szesnaście lub osiemnaście jest bukolicznych, a część z nich to kleine Heldengeschichten, czyli dosłownie krótkie historie heroiczne ${ }^{20}$.

Inny antyczny poeta, którego utwór wpłynął na kształtowanie się zjawiska epyllionu, to Katullus, autor carmen $64^{21}$, którego wyjątkowość zauważyli już humaniści. Spierali się co do tytułu dzieła

16 Ibidem.

17 Theocriti Idyllia sex et triginta, cum scholiis in octodecim priora Z. Calliergi, Francofurti 1558, s. 3. Cyt. za: V. Masciadri, Concepts and Texts..., s. 8.

18 W filozofii platońskiej wyrażenie عĩő rozumiane jest jako „idea”, u Arystotelesa występuje w znaczeniu „forma” czy wręcz „rodzaj literacki” - zob. S. Stabryła,

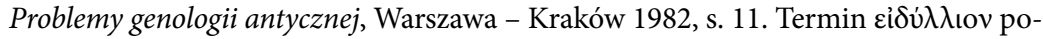
jawił się w nauce ponownie na początku XX wieku. Ulrich von Wilamowitz, podkreślając brak poświadczeń ze starożytności o tym jakoby epyllion był krótką epiką, nazwał eidyllionem utwór Kallimacha: das Eidyllion Hekale, Ulrich von Wilamowitz-Moellendorff, Hellenistische Dichtung in der Zeit des Kallimachos, Berlin 1924, s. 184.

19 Zob. V. Masciadri, Concepts and Texts..., s. 9.

20 Zob. F.L.C.F.G. von Filkenstein, Arethusa oder die bukolischen Dichter des Alterthums: Esther Teil, Berlin 1789, s. 14.

${ }^{21}$ Więcej na ten temat oraz uwagi krytyczne zob. m.in. G. Trimble, Catullus 64: The Perfect Epyllion?, w: Brill's Companion to Greek and Latin Epyllion and Its Reception, ed. by M. Baumbach, S. Bär, Leiden - Boston 2012, s. 55-81, oraz J. Styka, Estetyka epyllionu, w: Studia nad literatura rzymskq epoki republikańskiej, Kraków 1994, s. 157-167. 
ze względu na jego zróżnicowaną tematykę, jednak nie kojarzyli jeszcze tego utworu $\mathrm{z}$ charakterem narracyjnym i epiką: przeważały opinie o jego liryczności i związkach z pieśniami weselnymi ${ }^{22}$. Pierwszym krokiem do późniejszego przypisania temu utworowi miana epyllionu była analiza dokonana przez Johannesa Gurlitta w 1787 roku. Według niego początek pieśni mógłby sugerować jej przynależność do epitalamium, jednak skoro w dalszej części utworu nie pojawia się tradycyjny chór dziewcząt lub chłopców, tylko przemawia sam poeta, wskazuje to na charakter narracyjny ${ }^{23}$. To z kolei doprowadziło do uznania pieśni za: „eine kleine Epopee, wie das Gedicht des vermeintrichen Musäus von Hero und Leander, und wie fast alle Oßianischen Gedichte" 24 . Uwaga Gurlitta jest niezwykle istotna nie tylko ze względu na nazwanie carmen 64 krótkim eposem; stanowi także dowód na wpływ ówczesnej literatury na kształtowanie się zjawiska epyllionu. Uczony porównał bowiem twórczość Katullusa i Muzajosa do cyklu poematów epickich Osjana, postaci z mitologii irlandzkiej, opublikowanych w 1760 roku przez poetę Jamesa Macphersona. Zatem ówczesna dyskusja literacka, a ponadto rozwój w tym samym czasie krótkiej epiki w heksametrach podobnej do idylli nie mógł pozostać bez znaczenia dla rozwoju badań nad epyllionem antycznym, które już kilkadziesiąt lat później zaczęły stanowić istotną część pracy filologów klasycznych.

\section{Historia badań nad epyllionem}

Prawdopodobnie po raz pierwszy wśród uczonych nowożytnych termin $\dot{z} \pi u ́ \lambda \lambda ı$ ov odnoszący się do utworu starożytnego ${ }^{25}$ pojawił się

22 Zob. V. Masciadri, Concepts and Texts..., s. 7-10.

23 Zob. J. Gurlitt, Katulls epischer Gesang von der Vermählung des Peleus und der Thetis metrisch übersezt und mit einigen Anhängen begleitet, Leipzig 1787, s. 7.

24 Ibidem, s. 8.

25 Zachowało się sporo dawnych poświadczeń użycia terminu „epyllion”, zwłaszcza w krajach niemieckojęzycznych z okresu renesansu. Poświadczenia te nie należą 
w 1796 roku w wydaniu Hymnów Homeryckich Karla Davida Ilgena (Halle 1796). Określił on w ten sposób Hymn do Hermesa, używając greckiego alfabetu - świadczy to o tym, że termin ten był najprawdopodobniej dla uczonych obcy i nie rozpowszechnił się jeszcze w nauce, a co za tym idzie - jest to pierwsze lub przynajmniej jedno z pierwszych poświadczeń użycia tego określenia.

Po dwudziestoletniej przerwie termin ten znów pojawił się w tekście naukowym. Mimo iż nie dotyczył tekstu antycznego, lecz niemieckiego, odegrał bardzo ważną rolę w rozwoju nauki o epyllionie starożytnym oraz postrzeganiu go przez kolejnych uczonych XIX wieku, stanowiąc tym samym początek konceptualizacji tego terminu oraz jego rozprzestrzeniania się. W 1816 roku w roczniku Urania Friedrich Arnold Brockhaus zorganizował konkurs na napisanie krótkiego poematu w trzech kategoriach: poetycka narracja, idylla oraz list poetycki. Zwycięzcą został Ernst Schulze z utworem o dziewczynie, która przemienia się w różę: Die Bezauberte Rose. Utwór stał się bestsellerem w Niemczech, ale istotniejszy od samego poematu wydaje się komentarz jednego z członków jury, Adolpha Wagnera, który nazwał ten utwór „epyllionem lub idyllą"26. Istotne

jeszcze wprawdzie do naukowego rozpatrywania epyllionu, a jedynie do określania ówcześnie powstających poematów łacińskich i greckich. Jednakże to, jakim utworom autorzy przypisywali tę nazwę, może dać wskazówkę, jak wówczas ten termin rozumiano i jakie jego znaczenie przeszło na kolejne stulecia, a także - co najistotniejsze - jak owo znaczenie się zmieniło w stosunku do znaczenia starożytnego. W okresie renesansu były to zatem utwory pisane heksametrem lub dystychem elegijnym i liczyły od kilku wersów do kilkuset wersów. Na 8 przykładów takich utworów aż 7 odnosiło się do prawdziwych wydarzeń z życia (śmierć, małżeństwo, obchody Świąt Bożego Narodzenia, potwierdzenie stopni akademickich itd.). Jednemu z nich brakowało także spójnej narracji, dotyczył on magii i pełen był alegorii. Można więc przypuszczać, że w renesansie ten termin odnoszono do krótkich utworów o dość spontanicznej kompozycji, co oznacza dość luźne przejęcie znaczenia ze starożytności. Zob. S. Tilg, On the Origins of the Modern Term „Epyllion”..., s. 33-34.

26 A. Wagner, Ernst Schulze, Die bezauberte Rose, „Leipziger Kunstablatt für gebildete Kunstfreunde” 29 (1817), s. 12: „so stellt sich das Gedicht als Epyllion oder Idyllion”. Cyt. za: S. Tilg, On the Origins of the Modern Term „Epyllion”..., s. 39. 
jest zestawienie przez Wagnera tych dwóch gatunków, które mają ze sobą wiele wspólnego - mimo że nie nawiązywał on bezpośrednio do sielanek Teokryta, tylko do tych tworzonych w czasach mu współczesnych, to z pewnością ówcześni autorzy tworzący w tym gatunku opierali się na sielance antycznej. To zestawienie mogło mieć wpływ na opinie kolejnych uczonych - niedługo później wybrane idylle Teokryta zaczęto bowiem powszechnie uważać za epylliony ${ }^{27}$.

Niedługo potem, już w 1823 roku, Karl Otfried Müller w wydaniu Porwania Heleny Kolluthosa nazwał ten utwór „Das Epyllion des Koluthos" ${ }^{28}$, po czym można wnioskować, że był on zaznajomiony z tym wyrażeniem oraz pewny jego znaczenia. $\mathrm{W}$ tym czasie epyllion istotnie wydawał się terminem zadomowionym w słowniku uczonych niemieckich, choć używano go jeszcze do określania różnorodnych krótkich utworów narracyjnych od okresu archaicznego (aż piętnaście poświadczeń) przez okres hellenistyczny (dziewięć wzmianek) po późny antyk ( 2 adnotacje, obie odnoszące się do Kolluthosa) $)^{29}$.

Zaskakujące może być to, że najwięcej najstarszych wzmianek dotyczących epyllionu odnosi się do okresu archaicznego. Cechy charakterystyczne archaicznych eposów miniaturowych wyjaśnił Karl Müller w podręczniku do historii literatury greckiej, pisząc o twórczości Hezjoda ${ }^{30}$. Zamiast oryginalnej nazwy zapisanej greckimi literami lub łacińskiej transkrypcji użył niemieckich wyrażeń Epyllien oraz kleinen Epopöen; ponadto nazwał tego typu utwory interesującym gatu nkiem ${ }^{31}$. Dalej pisał, że epyllion jest mitologiczną

27 Zob. S. Tilg, On the Origins of the Modern Term „Epyllion”..., s. 39.

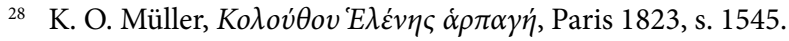

29 Zob. S. Tilg, On the Origins of the Modern Term „Epyllion”..., s. 42.

30 Zob. K. O. Müller, Geschichte der Grieschichen Literatur bis auf das Zeitalter Alexanders, Breslau 1841.

${ }^{31}$ Ibidem, s. 173: „eine interessante Gattung”. Warto dodać, że rok przed wydaniem tekstu oryginalnego (w języku niemieckim) ukazało się jego tłumaczenie na język angielski, zupełnie różnie traktujące najbardziej istotne kwestie związane z postrzeganiem epyllionu jako gatunku oraz powszechności tego terminu - 
historią heroiczną pisaną heksametrem, lecz bardziej pogodną i lekką niż tradycyjna epika ${ }^{32}$. Tom historii literatury opracowany przez Müllera dotyczył jedynie okresu archaicznego i prace nad kolejnymi tomami przerwała jego śmierć. Jednak Tilg stwierdził, że gdyby autor był w stanie opracować późniejsze epoki, prawdopodobnie przedstawiłby krótkie eposy również z okresu hellenistycznego i późnego antyku, skoro użył tego określenia do Porwania Heleny Kolluthosa ${ }^{33}$.

Wydaje się, że do 1855 roku nie było ani jednej wzmianki dotyczącej epyllionu łacińskiego. W drugiej połowie XIX wieku nagle znalazł się on w centrum zainteresowania dzięki pracy Moriza Haupta. Stanowi ona początek licznych badań nad carmen 64 Katullusa, uznawanego przez wielu późniejszych uczonych za „wzorcowy” epyllion oraz - co powtarzano za Hauptem - imitację epyllionów aleksandryjskich ${ }^{34}$. Zainteresowanie uczonych epyllionem łacińskim poskutkowało tym, że szerzej analizowane były również eposy miniaturowe hellenistyczne, głównie jako źródło epyllionów tworzonych na gruncie łacińskim przez neoteryków; jednocześnie okres archaiczny w badaniach nad epyllionem powoli przestawał być brany pod uwagę. Wtedy również rozpoczęła się debata uczonych na temat natury i istnienia epyllionu oraz tego, czy można uznać go za gatunek literacki. Opierała się ona jednak głównie na analizie carmen 64

zob. K.O. Müller, History of the Literature of the Ancient Greece, translated from the German manuscript by Sir G.C. Lewis and J. W. Donaldson, London 1840, s. 88: „An interesting kind (w oryginale niemieckim: Gattung) of composition attribuited to Hesiod are the smaller epics (po niemiecku: Epyllien), in which not a whole series of legends or a complicated story was described, but some separate events of the Heroic Mythology (...)”, [„Interesujący typ kompozycji przypisany Hezjodowi to krótkie eposy, w których nie był opisany szereg legend lub skomplikowana historia, lecz kilka oddzielnych wydarzeń z mitologii heroicznej"]. Zob. też: S. Tilg, On the Origins of the Modern Term „Epyllion”..., s. 43.

32 Zob. Müller, Geschichte der Grieschichen Literatur..., s. 173.

33 Zob. Tilg, On the Origins of the Modern Term „Epyllion”..., s. 44.

34 Zob. M. Haupt, Index lectionum quae auspiciis regis augustissimi Friderici Guilelmi Quarti in Universitate litteraria Friderica Guilelma per semestre aestivum habebuntur, Berlin 1855, s. 10. 
Katullusa oraz jego wzorów aleksandryjskich ${ }^{35}$, z których poeta korzystał - dzieło Kallimacha uznano zatem za prototyp formy, a utwór Katullusa za jej kulminację.

W drugiej połowie lat osiemdziesiątych XIX wieku epyllion wyszedł poza granice Niemiec: Robinson Ellis jako jeden z pierwszych uczonych wprowadził ten termin do nauki angielskiej (A Commentary on Catullus, Oxford 1876). Już rok później o epyllionie pisał także Charles Thomas Cruttwell w historii literatury rzymskiej (A History of Roman Literature, London - Edinburgh 1877); używał czcionki

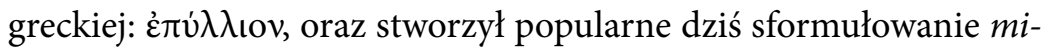
niature epic ${ }^{36}$.

Następny przełomowy moment $\mathrm{w}$ badaniach nad epyllionem przyniósł początek XX wieku - została wówczas opublikowana pierwsza praca w całości poświęcona zjawisku eposu miniaturowego: De epyllio Alexandrino Johanna Heumanna (Königsee 1904); wcześniej termin ten pojawiał się bowiem jedynie w krótkich wzmiankach dotyczących poszczególnych utworów. Heumann przedstawił ogólnie charakter poezji aleksandryjskiej, następnie omówił poszczególne utwory $^{37}$. Podkreślił we wstępie, że wśród poetów aleksandryjskich były dwie grupy: jedna podążała w swej twórczości za epiką home-

35 Zob. m.in. P.M. Weidenbach, De Catullo Callimachi Imitatore 1873, reprint: London 2013; W.Y. Sellar, The Roman Poets of the Republic, Oxford 1881; A. Couat, Étude sur Catulle, Paris 1882; Georges Lafaye, Catulle et ses modèles, Paris 1894.

36 Termin ten miał wówczas negatywny wydźwięk, podobnie jak ogólna ocena poezji hellenistycznej. Cruttwell uznał spostrzeżenia Kallimacha dotyczące $\mu \dot{\varepsilon} \gamma \alpha$

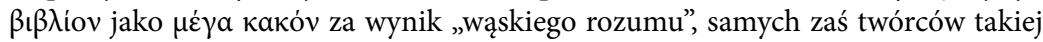
poezji mianował "wierszokletami”. Cruttwell, A History of Roman Literature, London - Edinburgh 1877, s. 124: „The maxim of Callimachus (characteristic as it is of his narrow mind) mega biblion mega kakon, a great book is a great evil, was the rule on which these poetasters generally acted” [„Maksyma Kallimacha (charakteryzująca jego ograniczony umysł) mega biblon mega kakon, wielka książka to wielkie zło, była zasadą, wedle której ci wierszokleci zwykle tworzyli”].

37 Autor podzielił je na zachowane (utwory Teokryta i Moschusa), niezachowane - lecz uznawane za epylliony ( $m$. in. Hekale Kallimacha) oraz te, których przynależność do epyllionu jest wątpliwa. 
rycką, druga ad nova tendebat - dążyła do nowego ${ }^{38}$. Efektem były krótkie utwory narracyjne, które nazywa się epyllionami, jednak użycie tego wyrażenia może być mylące, ponieważ każdy z uczonych nadał mu nieco inne znaczenie przy jednoczesnym nullo exemplo antiquo, czyli przy braku poświadczeń ze starożytności ${ }^{39}$.

W roku 1913 powstała pierwsza amerykańska rozprawa poświęcona temu gatunkowi. Carl Newall Jackson zajął się definicją i charakterystyką epyllionu, dzieląc wszystkie tego typu utwory na dwie grupy: heroiczne oraz romantyczne, obie pisane w heksametrach i manierze epickiej ${ }^{40}$. Zauważył także, że epyllion to niejako gatunek eksperymentu i emocji - pojawiał się bowiem w twórczości poetów w czasach jakiegoś przełomu i przemian ${ }^{41}$. Najpierw rozwijał się w epoce hellenistycznej, okresie kryzysu wartości poważanych wcześniej, w świecie archaicznej Grecji. Opisy chwały i heroicznych czynów zastąpione zostały skupieniem na człowieku, na mitach bar-

38 Zob. J. Heumann, De epyllio Alexandrino, Königsee 1904, s. 5.

39 Ibidem.

40 Należy nadmienić, iż Jackson uznał kwestię metrum za konstytutywną dla epyllionu - heksametr miałby oddzielać epyllion od elegii, nierzadko podobnej do epyllionu po względem tematyki i sposobu budowania narracji. Nie były jednak wtedy znane papirusy z Lille, odkryte w 1973 roku. Zawierają one fragmenty utworu Kallimacha Zwycięstwo Bereniki, mającego stanowić początkową część Warkocza Bereniki. Pod względem stylu i tematyki utwór doskonale wpasował się w konwencję epyllionu, kwestią sporną pozostawał jednak dystych elegijny, co stało się przyczynkiem do badań nad „epyllionem elegijnym”. Pierwszą uczoną, która poruszyła ten problem, była Therese Fuhrer, użyła bowiem określenia „elegische Epyllion” w odniesieniu właśnie do Zwycięstwa Bereniki - zob. T. Fuhrer, Die Auseinandersetzung mit den Chorlyrikern in den Epinikien des Kallimachos, „Schweizerische Beiträge zur Altertumswissenschaft" 23, Basel - Kassel 1992, s. 106-107 i 220. Zob. też: P.J. Parsons, Callimachus: Victoria Berenices, „Zeitschrift fur Papyrologie und Epigraphik" 25 (1977), s. 1-50; A. Palmore, Callimachus' Victoria Berenices: A Case Study in Elegiac Epyllion, „Aitia” 2016, no. 6.

${ }_{41}$ C.N. Jackson, The Latin Epyllion, „Harvard Studies in Classical Philology” 24 (1913), s. 4: „The epyllion was born of revolt; it constituted a protest against the methods pursued by the poets of the old-fashioned epic” [„Epyllion narodził się $\mathrm{z}$ buntu; stanowił protest przeciwko metodom ustanowionym przez poetów staromodnej epiki"]. 
dziej bliskich jednostce. Epyllion wywodzący się z Grecji przeniknął do literatury łacińskiej w twórczości neoteryków, poddających się wpływom poezji aleksandryjskiej. Kolejnym okresem, w którym pojawiło się wyjątkowo wysokie zainteresowanie epyllionem, był znów czas przełomu, czyli późny antyk.

W 1931 roku powstała bardzo istotna dla rozwoju nauki o epyllionie rozprawa doktorska z Oxfordu - szerokie opracowanie autorstwa Mary Marjorie Crump obejmujące historię i charakterystykę epyllionu od Teokryta aż po Owidiusza, które przez kolejne pięćdziesiąt lat stanowiło najbardziej rozbudowaną pracę dotyczącą tej tematyki, w całości poświęconą epyllionowi, obejmującą zarówno pieśni greckie, jak i rzymskie różnych autoró ${ }^{42}$. Crump oraz wcześniejsi wymienieni uczeni przyjmowali obecność epyllionu w literaturze za pewnik, jednakże już kilka lat później powstał artykuł całkowicie przeciwny wszelkim dotychczasowym badaniom nad rozwojem tej konwencji - amerykański uczony Walter Allen poddał krytyce wysiłki każdego z filologów badających zjawisko epyllionu jako gatunku, a pracę Crump uznał za "całkowitą pomyłkę"43. Podkreślał m.in., że w starożytności nie istniał termin „epyllion” w takim

42 M.M. Crump, The Epyllion from Theocritus to Ovid, Oxford 1931. Autorka zawarła w swej pracy wiele cennych dla zrozumienia epyllionu spostrzeżeń. Uważała, że grecki epyllion narodził się z tradycji powstałej w hymnach homeryckich oraz krótkich epizodach narracyjnych, które urozmaicały monotonię hezjodejskich katalogów. Rozróżniła dwa typy epyllionu greckiego: idylliczny (Teokryt) oraz narracyjny (Hekale Kallimacha) - twierdziła, że to wspomniani autorzy zapoczątkowali tę formę i przyczynili się jej rozpowszechnienia, dlatego u nich należy szukać cech powielanych przez kolejnych autorów. Zwróciła uwagę na realizm, obecność realistycznych detali w opisach, co w połączeniu z miłosną tematyką miało sprawiać, że utwór był lżejszy i bliższy zwykłemu czytelnikowi (s. 28-31). Rozwój łacińskiego eposu miniaturowego autorka podzieliła z kolei na trzy etapy: Katullus i jego szkoła, następnie Wergiliusz i Korneliusz Gallus, a na końcu epoka poetów augustowskich, przy czym ostatni etap był w jej mniemaniu najbardziej rozwinięty - wskazała tu na obecność bardziej skomplikowanej fabuły, liczne wątki romansowe, analizę psychologiczną bohaterów, pełne uczuć opisy czynów, a nawet sceny w typie horroru (s. 40).

${ }^{43}$ Zob. W. Allen, The Epyllion..., s. 2. 
znaczeniu, $w$ jakim przejęli je filologowie nowożytni ${ }^{44}$, dlatego należy według niego usunąć ten termin ze słownika krytyki literackiej i przestać przypisywać tej grupie jakiekolwiek utwory ${ }^{45}$. Atak Allena nie spotkał się z odzewem uczonych, opublikował on zatem kolejną pracę krytykującą epyllion jako gatunek pod wymownym tytułem The Non-Existent Classical Epyllion ${ }^{46}$. Mimo to druga połowa XX wieku przyniosła rozkwit badań nad charakterem oraz pochodzeniem epyllionu; dopiero najnowsze publikacje podejmują problem genologiczny na nowo ${ }^{47}$.

\section{Próba podsumowania: status quaestionis}

Od ponad dwustu lat historia epyllionu kształtuje się jako studium ukazujące, w jaki sposób „wynalezienie” gatunków literackich może modelować postrzeganie tekstów antycznych. Termin „epyllion” wyłonił się bowiem nie z teorii genologicznej (ani z samej twórczości poetyckiej) autorów klasycznych, lecz raczej ze współczesnej koncepcji literatury kładącej cień na rozumienie tekstów starożytnych. Uderzające jest, że w czasie, gdy starożytny epos miniaturowy pojawił się w polu badawczym, powstająca wówczas niemieckojęzyczna literatura odznaczała się podobieństwem do poezji idyllicznej, a na-

44 Podobnego argumentu używał David Bright. Według niego nikt wśród starożytnych filologów nie określił żadnych zasad, na jakich miałby opierać się epyllion, a jedyną cechą, która charakteryzuje to zjawisko literackie, jest aleksandryjskie upodobanie do eksperymentu oraz otwartość na zmiany stylu - zob. Bright, The Miniature Epic in Vandal Africa..., s. 6.

45 Zob. W. Allen, The Epyllion..., s. 25.

46 W. Allen, The Non-Existent Classical Epyllion, „Studies in Philology” 55 (1958), no. 3, s. 515-518.

${ }_{47}$ Zob. J. Styka, Estetyka epyllionu..., oraz S. Bär, Inventing and Deconstructing Epyllion: Some Thoughts on a Taxonomy of Greek Hexameter Poetry, w: Stereotyped Thinking in Classics. Literary Ages and Genres Re-Considered, ed. by C. Walde, „Thersites" 2 (2015). 
zywana była właśnie epyllionem. Wkrótce termin ten zaczął być używany do określania greckich utworów antycznych - zbieżność ową trudno uznać za w pełni przypadkową.

Warto jednocześnie pamiętać, że starożytni teoretycy literatury poruszali w swych dziełach kwestie dotyczące jedynie najbardziej kanonicznych gatunków. Jak zauważył Alan Cameron, autorzy epyllionów hellenistycznych byli nazywani przez późniejszych badaczy jak wszyscy inni poeci epiccy: é̉nođotó $\varsigma^{48}$. Oznacza to, że skoro każdy

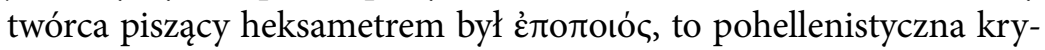
tyka literacka $\mathrm{w}$ żaden sposób nie traktowała (i nie miała potrzeby traktować) epyllionu jako autonomicznego gatunku - zatem brak wzmianek w teorii literackiej o krótkich formach (czy też innych, niewywodzących się z epoki archaicznej) nie może wykluczać ich statusu jako gatunku. Sam epyllion Cameron uznał natomiast za post-Callimachean development ${ }^{49}$, naturalny efekt ewolucji gatunkowej.

Przy próbach zdefiniowania epyllionu konieczne jest zwrócenie uwagi na jego otwartość na wpływy innych gatunków, z pozoru niepowiązanych ze sobą, jednak ostatecznie tworzących spójną całość ${ }^{50}$. Czy można zatem nazwać go nowym stylem epickiej narracji zawartej w poetyckiej formule genus mixtum, typowej dla gatunkowego pomieszania? Podlegała ona daleko idącej zasadzie variatio, dlatego każdy tworzony w tej formule utwór (epyllion) byłby tak oryginalny i niepodobny pod względem „,eech charakterystycznych" do innych epyllionów. Dużym uproszczeniem byłoby jednak stwierdzenie, że epyllion to po prostu pomieszanie różnych gatunków - należy

48 Zob. A. Cameron, Callimachus and His Critics, Princeton 1995, s. 268.

49 Ibidem, s. 452.

${ }_{50} \mathrm{~W}$ poetyce epoki hellenistycznej oraz $\mathrm{w}$ opartej na niej poetyce literatury łacińskiej często spotkać można zjawisko „przekraczania granic” gatunkowych. Niemiecki filolog Wilhelm Kroll jako pierwszy pisał o charakterystycznym dla literatury tych okresów krzyżowaniu gatunków (die Kreuzung der Gattungen) jako o najważniejszym aspekcie ówczesnej poetyki. Zob. W. Kroll, Studien zum Verständnis der römischen Literatur, Stuttgart 1924. Tytuł rozdziału 9, s. 202-224: Die Kreuzung der Gattungen. 
nadmienić, że niektóre gatunki pojawiały się w epyllionie częściej,

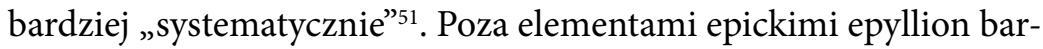
dzo często zawierał wyraźny odcień liryczny - głównie ze względu na długie wypowiedzi bohaterów, zwłaszcza kobiecych (np. pieśń Carme w Ciris). Ponadto budowa krótkiego eposu nierzadko przypominać mogła tragedię: autorzy często wybierali z całego mitu kilka kluczowych scen, pomiędzy którymi brakowało płynnych przejść czy nawet fragmentów historii istotnych dla fabuły, liczba bohaterów była niewielka, a ich działaniami kierował zwykle tragiczny błąd, z którego nie dało się wybrnąć. W tej kwestii utwór godny analizy to m.in. De raptu Helenae Drakoncjusza. Odnajdziemy w epyllionie również cechy wspomnianej wcześniej elegii, a także satyry, sielanki czy nawet mimu - choć te już rzadziej.

Wśród uczonych przeważają opinie, wedle których epyllion można uznać za koherentny gatunek; głosy całkowicie przeciwne tej teorii są nieliczne, z kolei niektórzy w taktyczny sposób zaliczają krótki epos po prostu do epiki: „epic is the most obvious and natural category” [„,epika jest najbardziej oczywistą i naturalną kategorią"], jak pisał Gregory Hutchinson o epyllionie kallimachejskim Hekale ${ }^{52}$. W moim odczuciu autorzy starożytni $w$ ten właśnie sposób rozumieli epyllion, czy wręcz: w takim zamyśle go tworzyli - jako swoisty typ epiki, zmieniającej się z biegiem czasu jak każdy inny gatunek oraz mającej inny charakter zależnie od epoki, autora czy podejmowanego tematu. Im krótszy utwór, tym wyraźniejsze i w większym stopniu nagromadzone w nim były cechy eposu i innych gatunków (czyli ogólnie cechy prawie całej antycznej poezji, której twórcy bardzo często przekraczali granice gatunkowe). Epyllion byłby zatem efektem naturalnej ewolucji epiki jako swoiste genus mixtum - choć i to stwierdzenie pozostawić warto w status quaestionis.

51 Zob. A.M. Wasyl, Genres Rediscovered: Studies in Latin Miniature Epic, Love Elegy, and Epigram of the Romano-Barbaric Age, Kraków 2011, s. 20-21.

52 G.O. Hutchinson, Talking Books: Readings in Hellenistic and Roman Books of Poetry, Oxford 2008, s. 66. 


\section{Bibliografia}

Allen W., The Epyllion: A Chapter in the History of Literary Criticism, „Transactions and Proceedings of the American Philological Association" 71 (1940), s. 1-26.

Allen W., The Non-Existent Classical Epyllion, „Studies in Philology” 55 (1958) no. 3, s. $515-518$.

Arystoteles, Poetyka, przeł. H. Podbielski, Wrocław 2006.

Aristotelis de arte poetica liber, rec. G. Christ, Lipsiae 1907.

Asmis E., Neoptolemus and the Classification of Poetry, „Classical Philology” 87 (1992), no. 3, s. 206-231.

Bär S., Inventing and Deconstructing Epyllion: Some Thoughts on a Taxonomy of Greek Hexameter Poetry, w: Stereotyped Thinking in Classics. Literary Ages and Genres Re-Considered, ed. by C. Walde, „Thersites” 2 (2015), s. 23-51.

Bright D., The Miniature Epic in Vandal Africa, London 1987.

Brill's Companion to Greek and Latin Epyllion and Its Reception, ed. by M. Baumbach, S. Bär, Leiden - Boston 2012.

Cameron A., Callimachus and His Critics, Princeton 1995.

D’Agostino V., Considerazioni sull'epillio e sull'idillio nell'età ellenistica, „Rivista di Studi Classici" 4 (1956), s. 31-40.

Filkenstein F.L.C.F.G., Arethusa oder die bukolischen Dichter des Alterthums: Esther Teil, Berlin 1789.

Filodemos, O muzyce. O utworach poetyckich. Epigramy, przeł. K. Bartol, Warszawa 2002.

Fuhrer T., Die Auseinandersetzung mit den Chorlyrikern in den Epinikien des Kallimachos, „Schweizerische Beiträge zur Altertumswissenschaft” 23, Basel - Kassel 1992.

Gurlitt J., Katulls epischer Gesang von der Vermählung des Peleus und der Thetis metrisch übersezt und mit einigen Anhängen begleitet, Leipzig 1787.

Gutzwiller K., Studies in the Hellenistic Epyllion, Königstein 1981.

Heumann J., De epyllio Alexandrino, Königsee 1904.

Hutchinson G.O., Talking Books: Readings in Hellenistic and Roman Books of Poetry, Oxford 2008.

Jackson C.N., The Latin Epyllion, „Harvard Studies in Classical Philology” 24 (1913), s. 37-50.

Kroll W., Studien zum Verständnis der römischen Literatur, Stuttgart 1924.

Lucilius, Satires, texte établi, trad. et annoté par F. Charpin, Paris 1978.

Masciadri V., Before the Epyllion: Concepts and Texts, w: Brill's Companion to Greek and Latin Epyllion and Its Reception, ed. by M.Baumbach, S. Bär, Leiden - Boston 2012, s. 3-28.

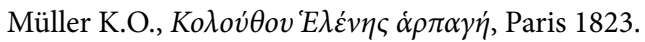


Palmore A., Callimachus' Victoria Berenices: A Case Study in Elegiac Epyllion, „Aitia” 2016, no. 6.

Parsons P. J., Callimachus: Victoria Berenices, „Zeitschrift fur Papyrologie und Epigraphik", nr 25 (1977), s. 1-50.

Perrotta G., Arte e tecnica nell'epillio alessandrino' in poesia ellenistica: scritti minori, Roma 1923.

Platonis Opera, ed. J. Burnet, Oxford 1903.

Reilly J.F., Origins of the Word Epyllion, „Classical Journal” 49 (1953), s. 111-114.

Stabryła S., Problemy genologii antycznej, Warszawa - Kraków 1982.

Styka J., Estetyka epyllionu, w: Studia nad literatura rzymska epoki republikańskiej, Kraków 1994, s. 157-167.

Tilg S., On the Origins of the Modern Term „Epyllion”: Some Revisions to a Chapter in the History of Classical Scholarship, w: Brill's Companion to Greek and Latin Epyllion and Its Reception, ed. by M. Baumbach, S. Bär, Leiden - Boston 2012, s. $29-54$.

Wasyl A.M., Genres Rediscovered. Studies in Latin Miniature Epic, Love Elegy, and Epigram of the Romano-Barbaric Age, Kraków 2011. 